\title{
Wasted efforts: why captivity is not the best way to conserve species
}

Miguel Pedrono

\begin{abstract}
Conservation strategies of Malagasy turtles and tortoises are based principally on the captive-breeding of these species, with the ultimate aim of their possible reintroduction in the wild. Given the current precarious conservation status of endemic Malagasy turtle and tortoise species, it is clear that this approach has been a failure. Instead of being used to complement in situ approaches for a number of years captive-breeding efforts have been used as an alternative. It is essential to develop conservation strategies for these species based on empirical data, and not only on the subjective vision of NGOs with a strong interest in ex situ conservation approaches. It is only by fighting the causes of decline of Malagasy chelonian species in the wild that they will be able to be saved.
\end{abstract}

\section{RÉSUMÉ}

Les stratégies de conservation des tortues malgaches reposent principalement sur l'élevage en captivité de ces espèces, en vue de leur possible réintroduction dans la nature. Force est de constater que cette approche a conduit à un échec, au regard du statut actuel, particulièrement précaire, des tortues endémiques malgaches. Au lieu d'appuyer les efforts de conservation in situ comme il se doit, l'élevage en captivité s'est substitué à eux, et ce depuis de nombreuses années. II est désormais essentiel d'élaborer les stratégies de conservation de ces espèces sur la base de données empiriques, et non plus sur la seule vision subjective d'ONGs présentant un fort intérêt pour l'approche ex situ. C'est seulement en combattant les causes du déclin des tortues malgaches qu'il sera possible d'assurer leur survie.

\section{MALAGASY TORTOISES EMBARK IN THE ARK}

In Madagascar, most species-oriented conservation projects have focused on either tortoises or lemurs. However, the conservation approaches developed for these two groups are very different even though the factors threatening their survival in the wild are quite similar. Most conservation projects developed for Malagasy lemurs are focused on protection of wild populations and critical habitats, whereas conservation efforts for chelonians are focused on captive-breeding. In captive-breeding efforts, a few individuals extracted from wild populations, or already captive individuals, are bred in captivity to produce so called 'assurance colonies', both in-country and overseas (e.g., Seal 1986, Soulé et al. 1986, Tudge 1992).
CIRAD (Centre de Coopération Internationale Recherche Agronomique pour le Développment), Ampandrianomby BP 853, Antananarivo, 101 Madagascar

E-mail: miguel.pedrono@cirad.fr

Historically, this has been the approach for four threatened Malagasy chelonians: the ploughshare tortoise (Astrochelys yniphora, Figure 1) by Juvik et al. (1982) and implemented by the Durrell Wildife Conservation Trust (DWCT) since 1986; the Madagascar side-necked turtle (Erymnochelys madagascariensis) by Kuchling (1997) and also implemented by DWCT since 1998; and the radiated tortoise (Astrochelys radiata) and the spider tortoise (Pyxis arachnoides) implemented by the Station d'Observation et de Protection des Tortues et de leurs Milieux (SOPTOM) since 2002. Additional 'assurance colonies' have been established by members of the Turtle Survival Alliance (TSA) in US and Europe for most of these species during the same period.

Catalysed by the commencement of activities by TSA and the Turtle Conservancy (TC) in Madagascar, and by an IUCN/ SSC workshop in Antananarivo in January 2008 and followed by two additional workshops on the same subject at a TSA meeting in Florida in 2010 and in Mahajanga in September 2011, interest in conservation projects for Malagasy tortoises has spiked dramatically in recent years. The workshops have had important implications for the trajectory of conservation activities: the main output of this series of workshops was the development of Conservation Strategies and Action Plans with a dominant ex situ component.

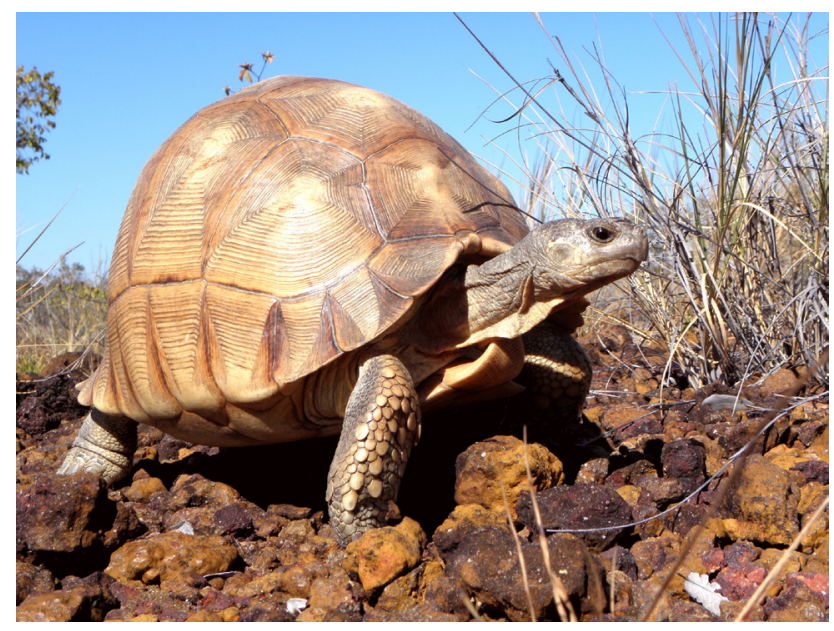

FIGURE 1: Female ploughshare tortoise (Astrochelys yniphora) in Baly Bay National Park. By Miguel Pedrono 


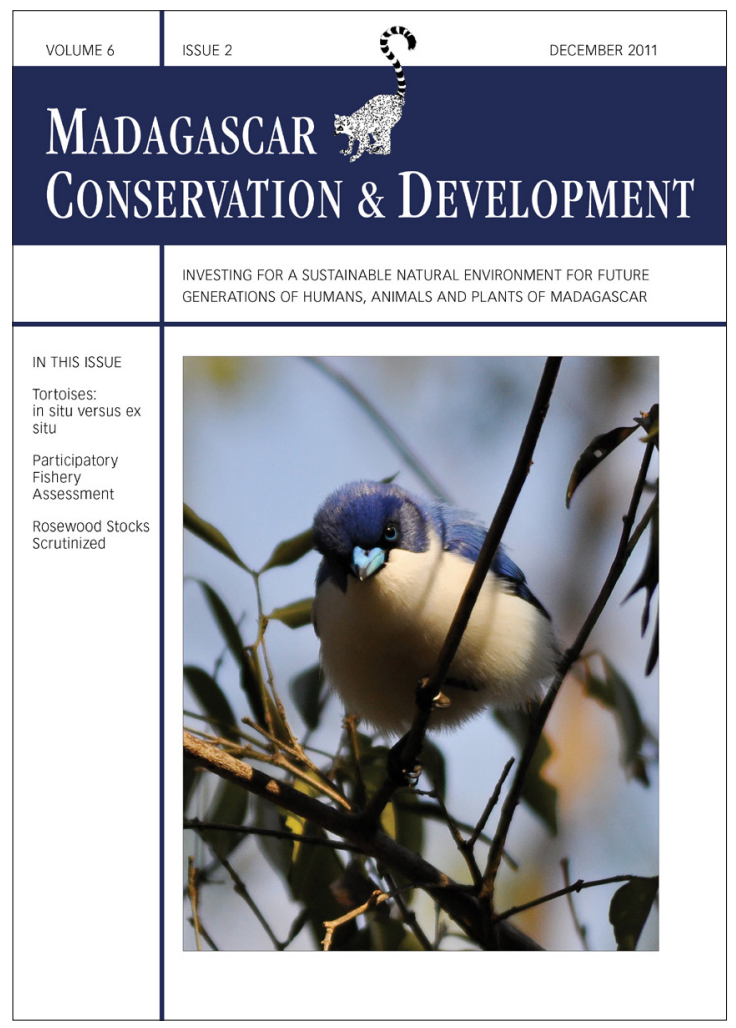

Madagascar Conservation \& Development is the journal of Indian Ocean e-Ink. It is produced under the responsibility of this institution. The views expressed in contributions to MCD are solely those of the authors and not those of the journal editors or the publisher.

All the Issues and articles are freely available at http://www.journalmcd.com

Contact Journal MCD

info@journalmcd.net for general inquiries regarding MCD funding@journalmcd.net to support the journal

Madagascar Conservation \& Development Institute and Museum of Anthropology University of Zurich

Winterthurerstrasse 190

CH-8057 Zurich, Switzerland

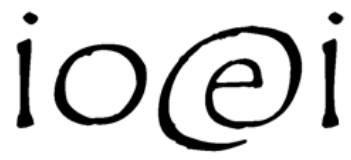

Indian Ocean e-Ink

Promoting African Publishing and Education www.ioeink.com

Missouri Botanical Garden (MBG)

Missouri Botanical Garden

Madagascar Research and Conservation Program BP 3391

Antananarivo, 101, Madagascar 


\section{AN UTTER WASTE OF CONSERVATION RESOURCES}

The buzz of recent activity could lead one to believe that Malagasy chelonians are now in a more secure position than most other groups of vertebrates in Madagascar. Unfortunately this is not the case. In fact, despite the long history of several of these conservation programs and the recent high profile workshops, Malagasy tortoise and turtle populations have never been in such jeopardy. All the endemic chelonians were even classified as 'Critically Endangered' on the IUCN Red List following the Antananarivo workshop in January 2008 (although such an extreme categorisation is certainly exaggerated for several species, Pedrono In prep.). Why? I believe that both the past and current generation of conservation projects focus too strongly on captive rather than on wild populations and that this approach has been totally ineffective. Considerable experience has shown that the most effective conservation strategies for tortoises and turtles target conservation of reproductive adults in the wild (e.g., Frazer 1992, Congdon et al. 1994). There is little sense in treating the symptoms but not the underlying causes of the decline of tortoise and turtle populations. I believe that the potential benefits of ex situ initiatives - including fostering public support and funding for the protection of chelonians - are outweighed by the fact that such approaches divert attention and resources from efforts to conserve wild populations that still have a chance to recover. Think of what could have been done with money wasted in overly expensive captive-breeding projects for in situ conservation and restoration efforts. Captive-breeding and reintroduction also have the potential to decrease genetic variability within species, to transmit exogenous pathogens to wild populations, and are done without any notion of the particular species' minimum viable population size (Snyder et al. 1996). Thus, ex situ conservation options should never be implemented as a priority over in situ approaches; rather they should be used to supplement them as demonstrated in the case of the ploughshare tortoise (Astrochelys yniphora). Modelling of wild and captive populations of ploughshare tortoise has clearly demonstrated that its long term survival depends essentially of the conservation of wild adults, but provided they are conserved, the release of captive-bred juveniles to the wild can contribute to boost the overall species recovery (Pedrono et al. 2004). Captive-breeding per se has limited utility for conservation that is only worthwhile under certain specific scenarios, i.e. when captive-breeding has a high probability of changing the extinction risk of species. Even the world's leading zoos who once touted the 'Ark Paradigm' to compensate for the loss of biodiversity in the wild, now largely acknowledge its limitations (Lees and Wilcken 2009).

\section{CONSERVATION STRATEGIES SHOULD BE BASED ON EMPIRICAL EVIDENCE}

The bias in allocation of conservation efforts for chelonians in Madagascar may result from the relative ease with which these species adapt to captivity and to reintroduction in the wild. This is not the case for lemurs, for which the stress induced by capture, transport, release procedures and social disturbance appear much more important, resulting in low reintroduction success (Britt et al. 2004). However, I don't believe that just because we can - we should. That is, this conservation option should not be prioritized over others just because tortoises and turtles are easy to breed in captivity and to reintroduce in the wild. This is especially true because such approaches have globally proven to be unsuccessful in reaching their ultimate objective: the continued existence of wild populations of chelonians in their natural habitat (Dodd and Seigel 1991, Frazer 1992). My main contention is that for optimal allocation of conservation efforts between wild and captive populations, decisions must be based on empirical evidence and not on the subjective judgement of those with a vested interest in ex situ conservation efforts over other types of conservation options. None of the breeding programs developed for chelonians in Madagascar to date have been based on quantitative analyses, but on the personal judgement of the concerned turtle hobbyists and related private NGOs. Although the 'assurance colonies' are generally presented as one component of these Action Plans for chelonian conservation, in reality, these captive-breeding projects are the cornerstones of these Action Plans. Such an approach appears to derive from the belief that there is a single miracle cure to the multiple problems that affect the diverse species addressed in the Action Plans, and perhaps the ease of demonstrating 'successful outcomes' in captive-bred populations; a must for any NGO that needs to demonstrate efficient use of donor funds.

\section{POSING THE RIGHT QUESTION}

The TSA, for example, was created by, and is funded almost exclusively by zoo professionals and avid turtle hobbyists who seek to play an important role in the conservation efforts of their favourite species. The fact TSA has emerged as a conservation organization does not necessarily steer them towards the fundamental question in species recovery: "Which management option will be the most effective to save a species?" Instead there is a propensity to commence from a basis of "How can captive-breeding programs be integrated into species conservation strategies?" It is therefore understandable that they are prone to orient chelonian conservation strategies towards ex situ approaches as they align most closely with the expressed mission and areas of expertise of this group. This is how TSA and SOPTOM decided to invest in the expansion of the facilities for 'assurance colonies' of radiated tortoises (Astrochelys radiata) and spider tortoises (Pyxis arachnoides) in southern Madagascar (Ogle and Hudson 2008). It was anticipated that tortoises confiscated from the international trade and captive-bred individuals could be used to supplement wild populations to a self-sustaining level, or to re-establish these species in parts of their former range. Despite the fact that wild populations of these species are in severe decline (O'Brien et al. 2003, Walker 2010), the justification for captive-breeding as a viable conservation measure is questionable at best, given the remaining large populations of both of these species in the wild (several million individuals of each species, Pedrono 2008). Conservation efforts should rather focus on effective measures to control the poaching of adult radiated and spider tortoises. And if those most closely involved in chelonian conservation don't believe that such a change is worthwhile let's put the question another way - would creation of 'assurance colonies' of endangered North-American or European tortoise and turtle species in Madagascar be acceptable to turtle hobbyists? 


\section{FIGHTING THE CAUSES OF THE PROBLEM}

Countries such as South Africa and India have successfully controlled the poaching of highly valued species - such as the African elephant and tigers - for the international trade in exotic species, and it should not be impossible for Madagascar to do the same for its tortoises and turtles, especially with the high levels of support of NGOs that have expressed their enthusiasm to play a leading role in their conservation. Some of these NGOs have already started to reorient their actions toward the preservation of wild populations particularly through financial support to antipoaching initiatives. My hope is that these approaches will soon overtake the old-fashioned ideas that focus on the repatriation of confiscated tortoises, rescue centers, and captive-breeding projects. Independent evaluation of existing projects and increased use of scientific analyses to forecast conservation project impacts may help to foster such a switch.

\section{ACKNOWLEDGEMENTS}

My sincere thanks go to Alison Clausen, Lora L. Smith and two anonymous reviewers for input and invaluable comments on the manuscript.

\section{REFERENCES}

Britt, A., Welch, C., Katz, A., lambana, B., Porton, I., Junge, R., Crawford, G., Williams, C. and Haring., D. 2004. The re-stocking of captive-bred ruffed lemurs (Varecia variegata variegata) into the Betampona Reserve, Madagascar: Methodology and recommendations. Biodiversity and Conservation 13, 3: 635-657. (doi:10.1023/B:BIOC.0000009497.24917.ae)

Congdon, J. D., Dunham, A. E. and Van Loben Sels, R. C. 1994. Demographics of common snapping turtles (Chelydra serpentina): Implications for conservation and management of long-lived organisms. American Zoologist 34, 3: 397-408. (doi:10.1093/icb/34.3.397)

Dodd, C. K. and Seigel, R. A. 1991. Relocation, repatriation, and translocation of amphibians and reptiles: Are they conservation strategies that work? Herpetologica 47, 3: 336-350.

Frazer, N. B. 1992. Sea turtle conservation and halfway technology. Conservation Biology 6, 2: 179-184. (doi:10.1046/j.15231739.1992.620179.x)

Juvik, J. O., Andrianarivo, A. J., Blanc, C. P. and Bour, R. 1982. Revised species recovery plan for the endangered Madagascar angulated tortoise (Geochelone $=$ Astrochelys yniphora). Unpublished proposal to the Department of Water and Forests of Madagascar and the World Wildlife Fund.

Kuchling, G. 1997. Captive propagation of Erymnochelys madagascariensis and a tortoise and turtle exhibit at Ampijoroa. Unpublished report to Conservation International and Jersey Wildlife Preservation Trust.

Lees, C. M. and Wilcken, J. 2009. Sustaining the Ark: The challenges faced by zoos in maintaining viable populations. International Zoo Yearbook 43, 1: 6-18. (doi:10.1111/j.1748-1090.2008.00066.X)

O'Brien, S., Emahalala, E. R., Beard, V., Rakotondrainy, R. M., Reid, A., Raharisoa, V. and Coulson, T. 2003. Decline of the Madagascar radiated tortoise Geochelone radiata due to overexploitation. Oryx 37, 3: 338-343. (doi:10.1017/S0030605303000590)

Ogle, M. and Hudson, R. 2008. Supporting efforts to protect Madagascar's endemic tortoises - TSA launches new program. Turtle Survival Alliance Newsletter, August 2008: 36-39.

Pedrono, M. 2008. The Tortoises and Turtles of Madagascar. Natural History Publications (Borneo). Kota Kinabalu, Sabah, Malaysia.

Pedrono, M., Smith, L. L., Clobert, J., Massot, M. and Sarrazin, F. 2004. Wildcaptive metapopulation viability analysis. Biological Conservation 119, 4: 463-473. (doi:10.1016/j.biocon.2004.01.007)

Seal, U. S. 1986. Goals of captive propagation programmes for the conservation of endangered species. International Zoo Yearbook 24, 1: 174-179. (doi:10.1111/j.1748-1090.1985.tb02535.x)
Snyder, N. F. R., Derrickson, S. R., Beissinger, S. R., Wiley, J. W., Smith, T. B., Toone, W. D. and Miller, B. 1996. Limitations of captive breeding in endangered species recovery. Conservation Biology 10, 2: 338-348. (doi:10.1046/j.1523-1739.1996.10020338.x)

Soulé, M., Gilpin, M., Conway, W. and Foose, T. 1986. The millennium ark: How long a voyage, how many staterooms, how many passengers? Zoo Biology 5, 2: 101-113. (doi:10.1002/zoo.1430050205)

Tudge, C. 1992. Last Animals at the Zoo: How Mass Extinction Can Be Stopped. Island Press, Washington, D.C.

Walker, R. C. J. 2010. The decline of the critically endangered northern Madagascar spider tortoise (Pyxis arachnoides brygooi). Herpetologica 66, 4: 411-417. (doi:10.1655/09-047.1) 